\title{
Molecular Proxies as Indicators of Freshwater Incursion-Driven Salinity Stratification
}

Svenja Tulipani $^{\mathrm{a}^{*}}$, Kliti Grice ${ }^{\mathrm{a} *}$, Paul F. Greenwood ${ }^{\mathrm{a}, \mathrm{b}}$, Lorenz Schwark ${ }^{\mathrm{a}, \mathrm{c}}$, Michael E. Böttcher ${ }^{\mathrm{d}}$, Roger E. Summons ${ }^{\mathrm{e}}$, Clinton B. Foster ${ }^{\mathrm{f}, \mathrm{g}}$

*Corresponding authors:

s.tulipani@curtin.edu.au, +61 (0)89266 7628

k.grice@ curtin.edu.au, +61(0)892662474

${ }^{a}$ WA Organic and Isotope Geochemistry Center, The Institute for Geoscience Research, Department of Chemistry, Curtin University, GPO Box U1987, Perth, WA 6845, Australia

${ }^{\mathrm{b}}$ Center for Exploration Targeting and Biogeochemistry Center, University of Western Australia, 35 Stirling Highway, Crawley WA 6009, Australia

${ }^{\mathrm{c}}$ Institute of Geoscience, Kiel University, Ludewig-Meyn Str. 10, 24118 Kiel, Germany

${ }^{\mathrm{d}}$ Geochemistry \& Isotope Biogeochemistry Group, Marine Geology Department, LeibnizInstitute for Baltic Sea Research, Seestrasse 15, D-18119 Warnemünde, Germany

${ }^{\mathrm{e}}$ Department of Earth, Atmospheric and Planetary Sciences, MIT, E25-633, 45 Carleton Street Cambridge, MA 02139 USA

${ }^{\mathrm{f}}$ Geoscience Australia, GPO Box 378, Canberra, ACT 2601, Australia

${ }^{g}$ School of Earth and Environment, The University of Western Australia, 35 Stirling Highway, Crawley, WA 6009, Australia 


\begin{abstract}
Salinity-related stratification in marine environments is one of the main drivers for the development of persistent anoxia and euxinia. It therefore plays a vital role in the sedimentary preservation of organic matter and has also been associated with Oceanic Anoxic Events during several mass extinctions in Earth's history.

Here we present a novel molecular proxy using relative abundances of methyltrimethyltridecylchromans (MTTCs) as indicators of riverine freshwater incursions into Middle to Late Devonian paleoreefs exposed to conditions of prevailing anoxia, photic zone euxinia and water column stratification. This paper aims at re-instigating a discussion about the origin of these compounds to potentially broaden their utilization as paleoproxies, adding freshwater stratification to the general salinity reconstructions. The co-variation of MTTC abundance profiles and $\delta^{13} \mathrm{C}$ values with other biomarker parameters in the sediments studied here indicate a link of MTTCs to terrigenous input, pointing towards a previously suggested early diagenetic formation of these compounds from phytol with higher plant-derived alkylphenols.
\end{abstract}

\title{
Keywords
}

Photic zone euxinia, salinity-stratification, MTTCs 


\section{Introduction}

Persistent salinity-related density stratification in marine environments, as observed in the modern-day Black Sea, has been a significant paleoenvironmental and paleoecological feature throughout Earth's history. Such stratification was particularly widespread during global oceanic anoxic events associated with mass extinctions (Summons and Powell, 1986; Grice et al., 2005; Meyer and Kump, 2008; Jaraula et al., 2013), and was often accompanied by photic zone euxinia (PZE). During PZE, enhanced concentrations of toxic hydrogen sulfide which are produced by anaerobic sulfate reducing bacteria in the sediments or even the water column extend to the photic zone (i.e. the upper part of the water column with sufficient light penetration to support photosynthesis). The few highly specialized organisms able to thrive under such hostile conditions include the obligately anaerobic green sulfur bacteria (Chlorobi), which grow directly at the chemocline where they can access hydrogen sulfide as an electron donor for anoxygenic photosynthesis. Therefore, the presence of characteristic ${ }^{13} \mathrm{C}$-enriched Chlorobi biomarkers (e.g. isorenieratane, I and related aryl isoprenoids, II, Figure A1), derived from carotenoid pigments in their unique photosystem, represents unequivocal evidence for paleoenvironmental PZE (Summons and Powell, 1986; Koopmans et al., 1996a, Grice et al., 2005). Another biomarker indicative of water column stratification is gammacerane (III), which is derived from tetrahymanol (IV) in bacterivorous ciliates living at the interface between stratified water layers (Harvey and McManus, 1991; Sinninghe Damsté et al., 1995). Whereas the biomarkers mentioned above are indicative of conditions in the lower part of a stratified water column, additional compounds such as methyltrimethyltridecylchromans (MTTCs, V) are proposed to reflect the conditions above the chemocline (Sinninghe Damsté et al., 1993). Although the specific origin and formation pathway of MTTCs $(\mathbf{V})$ in geological samples remain unclear, the ratio between different chroman isomers has been established as a reliable indicator 
for paleosalinity (e.g. Sinninghe Damsté et al., 1987, 1993; Schwark and Püttmann, 1990; Grice et al., 1998c; Schwark et al., 1998, Wang et al., 2011). Hypotheses for the formation of MTTCs (V) include direct biosynthesis by phytoplanktonic organisms (Sinninghe Damsté et al., 1993), early diagenetic condensation reactions of phytol with alkylphenols (e.g. from higher plantderived lignin) (Li et al., 1995; Tulipani et al., 2013) or cyclization of alkylphenols (Barakat and Rullkötter, 1997). MTTCs or appropriate diagenetic precursors have not been found in any organisms. Whilst biogenic tocopherols (VI) are structurally similar, the hydroxyl group at C6 disqualifies them as a possible precursor of sedimentary MTTCs (V), particularly because some geological MTTCs contain a methyl substituent at this position (Sinninghe Damsté et al., 1987, 1993; Li et al., 1995; Sinninghe Damsté and de Leeuw, 1995).

Here we present a new conceptual model with MTTCs $(\mathbf{V})$ as indicators of freshwater incursions and terrigenous input into a stratified marine paleoenvironment associated with Middle to Late Devonian reef systems. For this purpose we used biomarker, elemental and isotope parameters indicative of redox conditions, water column stratification, PZE and terrigenous input (associated with the rise of land plants) which have been determined throughout a core collected from the Canning Basin, Western Australia (Tulipani, et al. 2014), and related their variations to chroman ratios (5,7,8 trimethyl-MTTC/total MTTCs (Sinninghe Damsté et al., 1993)) and MTTC (V) abundances. More detailed information on the stratigraphic context, temporal variability and the significance of the described paleoenvironmental conditions for the Late Devonian extinction events is presented in a second paper Tulipani et al. (2014). The data most relevant for the molecular proxy introduced here are summarized in Figure A2. 


\section{Geological Setting}

The Canning Basin (Western Australia) is known for its extensive Middle to Late Devonian reef systems containing exceptionally well preserved macro (Long and Trinajstic, 2010) and molecular fossils (i.e. biomarkers) (Melendez et al., 2013a, 2013b). The samples for the present study originate from a core (MR-1) collected at the location of McWhae Ridge $\left(18.72796^{\circ} \mathrm{S}, 126.0682^{\circ} \mathrm{E}\right)$ and comprise interfingering marginal slope and basin facies (Sadler and Gogo formations, respectively). This study focuses mainly on the lower part of the core (40.1-42.1 m) from the Gogo Formation which was deposited in the latest Givetian or earliest Frasnian (dating based on palynological results, specifically, the occurrence of Archaeozonotriletes timanicus Naumova 1953, which is a characteristic element of Australian plant microfossil assemblages of the optivus-triangulatus zone (McGregor and Playford, 1993). It consists of laminated argillaceous shales and contains fragments of crinoids, stromatoporoids and brachiopods in some parts. Sediments from an overlying section of the core deposited later in the Frasnian (27.2-40.1m; dating based on relative stratigraphic position and conodonts (Trinajstic and Roelofs, pers. comm.)) were also analyzed and some data were included in this study. The lithology of the investigated core section is displayed in Figure A2. For a more comprehensive description and more geological details about the section at Mc Whae Ridge, see Tulipani et al. 2014 and references therein. All samples show an extraordinarily low maturity with very low $\mathrm{T}_{\max }$ values (Rock Eval analysis, 405 to $418^{\circ} \mathrm{C}$ ) accompanied by equally low values for molecular maturity parameters (e.g. Table A1 and Tulipani et al., 2014).

Throughout most of the Devonian the climate was tropical without polar ice caps. According to Joachimski et al. (2009) temperatures were slightly cooler in the Late Givetian with an average of $\sim 25^{\circ} \mathrm{C}$, but increased again throughout the Frasnian to $\sim 30^{\circ} \mathrm{C}$. Furthermore, there was a global sea-level rise from the Givetian to the Late Frasnian (Johnson et al., 1985), which 
has also been observed in the Canning Basin (Playford et al., 2009). The expansion of terrestrial plants, with the first forests occurring in the Givetian (Grice et al., 2009; Meyer-Berthaud et al., 2010; Mintz et al., 2010), likely had a major influence on climate and biogeochemical cycling (e.g. Algeo et al. 1995, 2001; Algeo and Scheckler 2010).

\section{Methods}

The methods summarized here have also been described in Tulipani et al. 2014. The MR1 core was collected with a small portable drilling-rig without the use of drilling fluids or lubricants. Samples were cut with a rock saw (diamond crystal edge with carbon steel center) and ultrasonicated in methanol and dichloromethane (DCM) to remove potential surface contamination. Subsequently, samples were powdered in a stainless-steel rock-mill and Soxhletextracted with $90 \%$ DCM in methanol (48h). Activated copper turnings were used for elemental sulfur removal. The extracts were separated by silica gel-column chromatography $(20 \mathrm{~cm}$ x 0.9 $\mathrm{cm}$ I.D.) using solvents with increasing polarity. The aliphatic and aromatic hydrocarbon fractions relevant for this study were eluted in hexane and $20 \%$ DCM in hexane, respectively. Procedural blanks were analyzed by gas chromatography-mass spectrometry (GC-MS) to monitor laboratory contamination.

GC-MS analyses were performed on an Agilent 5973 Mass-Selective Detector (MSD) interfaced to an Agilent 6890 gas chromatograph (GC) equipped with a HP 6890 auto-sampler and a DB-5MS capillary column (60 m length, $0.25 \mathrm{~mm}$ I.D., $0.25 \mu \mathrm{m}$ film thickness). The GCoven was heated from $40{ }^{\circ} \mathrm{C}$ to $310{ }^{\circ} \mathrm{C}$ (aliphatic fractions) or $325^{\circ} \mathrm{C}$ (aromatic fractions) at 3 ${ }^{\circ} \mathrm{C} / \mathrm{min}$ with initial and final hold times of 1 and 30 minutes, respectively. Perylene, isorenieratane and renieratane were identified by retention time correlation with authentic standards. Palaeorenieratane and MTTCs were identified by comparison of mass spectra and 
relative retention times reported by Hartgers et al. (1994) and Sinninghe Damsté et al., (1987), respectively. For semi-quantitative analyses (without consideration of response factors) the aromatic fractions were spiked with a known amount of perdeuterated terphenyl $\left(\mathrm{d}^{14}\right)$.

GC-irMS analyses were performed on a Micromass IsoPrime mass-spectrometer interfaced to an Agilent 6890N GC fitted with a 7683 autosampler. GC settings and column were identical to those used for GC-MS analyses. Each sample was analyzed at least in duplicate and average values and standard deviations were reported. Standard solutions containing compounds with a known isotopic composition were analyzed after every second sample to confirm accuracy of the instruments. For more details on acquisition parameters used for GC (e.g. injector, carrier gas), MS/irMS, interface (for GC-irMS) and instrument softwares see Melendez et al. (2013b).

To determine gammacerane indices, aliphatic fractions were analyzed on a Micromass Autospec Ultima MS (MRM-mode), which was interfaced to an Agilent 6890 N GC fitted with an autosampler and a DB-5MS fused silica capillary column (60 m; $0.25 \mathrm{~mm}$ I.D.; $0.25 \mu \mathrm{m}$ film thickness; J\&W Scientific). Helium (constant flow: $2 \mathrm{~mL} / \mathrm{min}$ ) was used as carrier gas. The GC oven was programmed from $60^{\circ} \mathrm{C}$ to $150^{\circ} \mathrm{C}$ at $10^{\circ} \mathrm{C} / \mathrm{min}$ and to $315^{\circ} \mathrm{C}$ at $3^{\circ} \mathrm{C} / \mathrm{min}$ with initial and final hold times of 2 and 24 min, respectively. The source was operated in $70 \mathrm{eV}$ electron impact mode at $250^{\circ} \mathrm{C}$, with $8 \mathrm{kV}$ accelerating voltage. Gammacerane indices were determined by monitoring the precursor-product reaction of $\mathrm{m} / \mathrm{z} 412$ to $\mathrm{m} / \mathrm{z}$ 191. Data were acquired and processed using MassLynx 4.0 (Micromass Ltd.) software. Identification of compounds was achieved by data comparison with a synthetic mixture of oils.

Fractions of the non-extracted powdered samples were decarbonated by the addition of hydrochloric acid ( 5\%), washed, dried and analyzed on a VARIO EL-III elemental analyzer for the determination of the carbon weight percentage $(\mathrm{C} \%)$. The carbonate content (weight percent) was inferred from the difference of sample weight before and after decarbonation. TOC\% was 
calculated from C\% in the decarbonated samples. RockEval pyrolysis was performed on the decarbonated samples using a VINCI Rock Eval 2 instrument. $\delta^{13} \mathrm{C}$ of carbonates was measured by continuous-flow (CF) analysis on a GasBench II coupled with a Delta XL Mass Spectrometer (Thermo-Fisher Scientific) after Paul and Skrzypek (2007). For the measurement of $\delta^{13} \mathrm{C}$ of organic carbon, fractions of the sample residues after Soxhlet-extraction were decarbonated by the addition of $\sim 7 \mathrm{~N}$ hydrochloric acid. Bulk $\delta^{13} \mathrm{C}$ analysis of the washed, dried and homogenized samples was performed on a continuous flow (CF) system consisting of a Delta V Plus mass spectrometer connected to a Thermo Flash 1112 via Conflo IV (Thermo-Finnigan/Germany). Combustion and oxidation were achieved at 1700 to $1800^{\circ} \mathrm{C}$ and reduction at $650^{\circ} \mathrm{C}$. For more details see Paul and Skrzypek (2006).

$\delta^{34} \mathrm{~S}$ of total reducible inorganic sulfur (TRIS) was measured in a fraction of the sample residue after Soxhlet-extraction. TRIS was extracted from the sample by treatment with hot acidic chromium (II) chloride (Fossing and Jørgensen, 1989). The generated $\mathrm{H}_{2} \mathrm{~S}$ was precipitated quantitatively as $\mathrm{ZnS}$, which was then converted to $\mathrm{AgS}_{2} \cdot{ }^{34} \mathrm{~S} /{ }^{\beta 2} \mathrm{~S}$ ratios were measured by combustion-isotope ratio monitoring-mass spectrometry (C-irm-MS) using a Thermo Finnigan MAT 253 mass spectrometer coupled to an elemental analyser (Thermo Flash 2000) via a split interface (Thermo Finnigan Conflo IV). Measured isotope ratios were calibrated with in-house and international reference materials (Mann et al., 2009) and reported in the $\delta$ notation relative to the V-CDT (Vienna Cañon Diablo Troilite) standard.

For palynological analysis small samples were taken throughout the core. These samples were not identical to the samples for biomarker, elemental and isotope analysis. They were processed using standard palynological techniques described by Wood et al. (1996). 


\section{Results and Discussion}

MTTCs (V) were present in all samples, with the 5,7,8 trimethyl-MTTC being by far the most abundant. The 6- and 8-methyl-MTTCs as well as the 5,8-, 6,8- and 7,8-dimethyl-MTTCs were also present.

Strong differences were evident between sediments of Late Givetian-Early Frasnian age and those deposited later in the Frasnian (Tulipani et al. 2014 and Figure A2). The earlier package of sediments represents the main focus of this study and is characterized by high gammacerane indices (gammacerane (III)/17 $\alpha, 21 \beta$-hopane, VII; 0.55 to 1.71, average 1.27), elevated perylene (VIII) concentrations as well as relatively low pristane (IX)/phytane (X; $\mathrm{Pr} / \mathrm{Ph})$ ratios $(0.39$ to 1.0 , average 0.55$)$. These features correlated with abundant Chlorobi biomarkers (Figure A3) and high chroman ratios ( 0.93 to 0.95 , average 0.94 ; see introduction for definition). Furthermore, $\delta^{13} \mathrm{C}$ values of carbonate ( +0.1 to $-3.0 \%$ ), $\mathrm{OM}$ and biomarkers (e.g. Tables 1 and A1) as well as $\delta^{34} \mathrm{~S}$ signatures of pyrite (Table 1) were relatively depleted in the heavy isotopes. In contrast the samples deposited later in the Frasnian showed high $\mathrm{Pr} / \mathrm{Ph}$ ratios (> 1) and lower chroman ratios (0.79 to 0.93 ; average 0.88 ). Gammacerane (III) and perylene (VIII) were only present at trace levels and Chlorobi biomarkers were absent. All the samples investigated in this study exhibited low TOC contents and exceptionally low thermal maturity (Tables 1 and A1).

\subsection{Reconstruction of the Depositional Environment}

Figure 1 schematically displays the paleoenvironmental setting corresponding to the Late Givetian-Early Frasnian age sediments of the MR-1 core, which was reconstructed using the biomarker and stable isotope parameters discussed hereafter. The disposition of reef systems formed a semi-enclosed basin in which the water column was stagnant due to restricted water 
exchange with the open ocean. The high MTTC (V) abundances and chroman ratios point towards predominantly riverine sources of freshwater which would have remained above the more saline hypolimnion (discussed in section 4.3). Density differences between these two layers prevented vertical mixing and created a sharp chemo-, pycno-, thermo- and halocline at the interface (Figure 1a). A modern analogue for these conditions is the Black Sea, where large rivers from Eastern Europe provide freshwater input and terrigenous runoff, supporting high primary productivity and density stratification leading to an oxygenated epilimnion of $\sim 50 \mathrm{~m}$ which is overlying deep sulfidic and anoxic waters (> $100 \mathrm{~m}$ ) (Murray et al., 2007).

In contrast, the sediments from the upper part of the core were deposited later in the Frasnian and were laid down in a less restricted setting at higher sea-levels (Playford et al., 2009) without indications of water column stratification, anoxia or PZE (e.g. absence of intact Chlorobi carotenoid derivatives, gammacerane at trace levels, $\mathrm{Pr} / \mathrm{Ph}>1$, lower chroman ratios, Tulipani et al. 2014). However, the intended focus of this work is the conceptual model of the paleoenvironment around the G-F boundary corresponding to the lower core section (42.1-40.1 $\mathrm{m})$. For a further discussion on conditions corresponding to the upper part of the core see Tulipani et al. (2014).

Table 1: Selected elemental, stable isotope and maturity parameters in Late Givetian-Early Frasnian sediments deposited in a stratified and anoxic/euxinic marine environment

\begin{tabular}{|c|c|c|c|c|c|c|c|c|c|}
\hline \multirow[b]{2}{*}{$\begin{array}{l}\text { Medium } \\
\text { depth } \\
\text { [m] }\end{array}$} & \multirow[b]{2}{*}{ TOC \% } & \multirow[b]{2}{*}{ Carb. \% } & \multirow[b]{2}{*}{ TOC/TS } & \multirow[b]{2}{*}{$\begin{array}{l}\mathrm{C}_{31} \text { hopane } \\
\mathrm{S} /(\mathrm{S}+\mathrm{R})\end{array}$} & \multicolumn{4}{|c|}{$\delta^{13} \mathrm{C}[\% \circ$ VPDB] } & \multirow[b]{2}{*}{$\begin{array}{l}\delta^{34} \text { Spyrite } \\
\text { [\%o VCDT] }\end{array}$} \\
\hline & & & & & pristane & phytane & $n$-alkanes $C_{19-21}$ & paleorenieratane & \\
\hline 40.2 & ${ }^{* *} 0.1$ & ${ }^{\star *} 62.6$ & 0.1 & ${ }^{* *} 0.23$ & n.d. & $\begin{array}{l}* *-33.5 \\
\pm 0.0\end{array}$ & -33.0 & n.d. & ${ }^{* *}-24.0$ \\
\hline 40.3 & ${ }^{* *} 0.3$ & **68.1 & 0.4 & ${ }^{* *} 0.20$ & n.d. & $\begin{array}{l}{ }^{*}-33.6 \\
\pm 0.2\end{array}$ & -32.8 & ${ }^{* *}-15.3 \pm 0.3$ & $* *-13.8$ \\
\hline 40.5 & ${ }^{* *} 0.9$ & $* * 15.2$ & 0.6 & n.d. & n.d. & n.d. & n.d. & n.d. & n.d. \\
\hline 40.7 & ${ }^{\star *} 0.8$ & ${ }^{* *} 10.5$ & 0.5 & ${ }^{* \star} 0.13$ & $\begin{array}{l}\text { a-33.2 } \\
\pm 0.1\end{array}$ & $\begin{array}{l}\text { a-32.9 } \\
\pm 0.4\end{array}$ & -32.3 & ${ }^{* *}-15.4 \pm 0.7$ & ${ }^{* *}-11.9$ \\
\hline 41.2 & ${ }^{* *} 0.7$ & **32.1 & 0.5 & ${ }^{\star \star} 0.12$ & $\begin{array}{l}\text { a-32.7 } \\
\pm 0.1\end{array}$ & $\begin{array}{l}\text { a-32.6 } \\
\pm 0.0\end{array}$ & -32.8 & n.d. & ${ }^{* *}-15.0$ \\
\hline 41.9 & ${ }^{* *} 0.7$ & ${ }^{* *} 13.3$ & 0.4 & ${ }^{* *} 0.11$ & n.d. & $\begin{array}{l}{ }^{*}-33.9 \\
\pm 0.4 \\
\end{array}$ & -33.4 & ${ }^{* *}-15.1 \pm 0.0$ & ${ }^{* *}-19.1$ \\
\hline
\end{tabular}




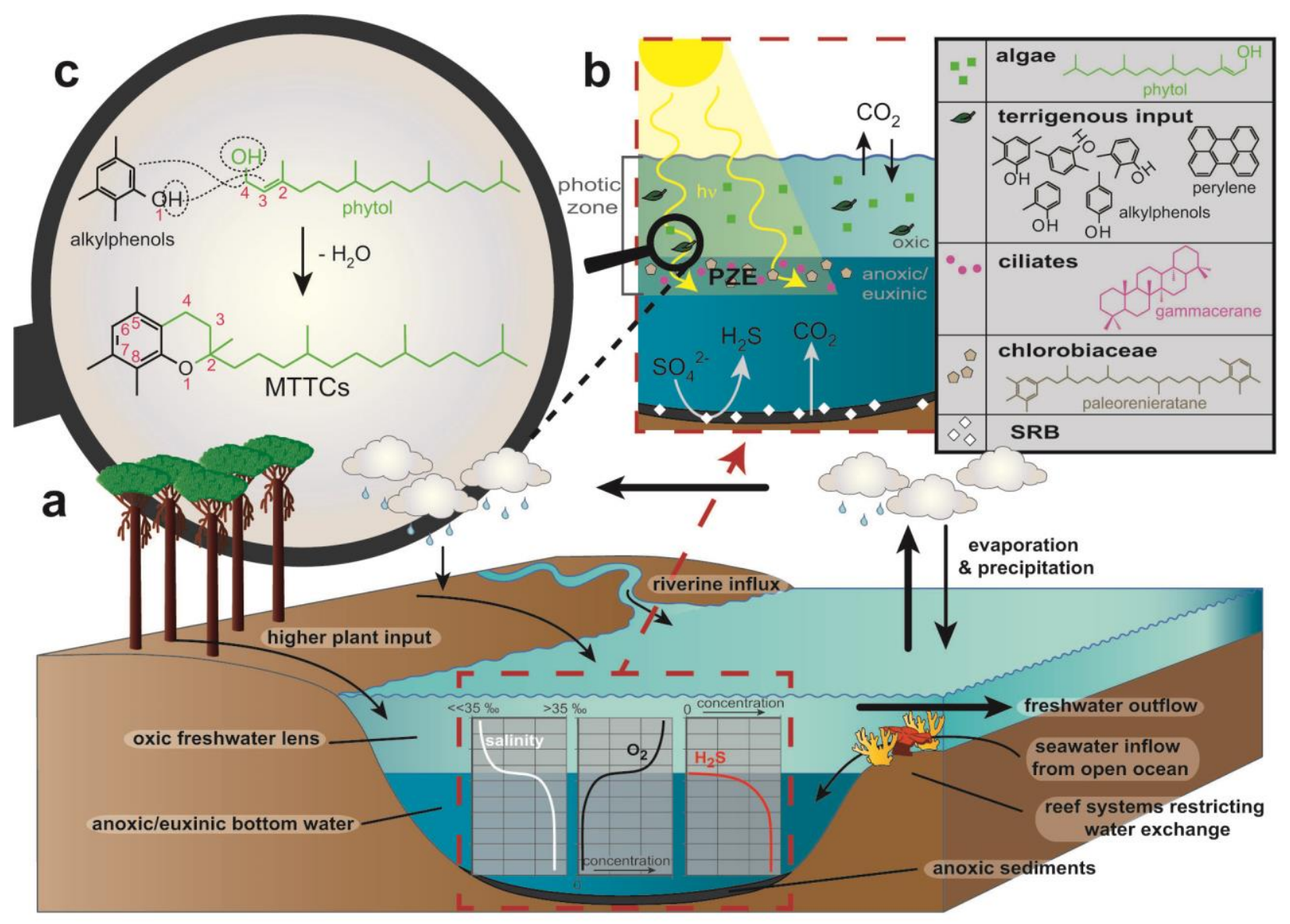

Figure 1: (a) Schematic model of the depositional conditions in the stratified Late GivetianEarly Frasnian paleoenvironment (Canning Basin) with freshwater incursions overlying more saline bottom waters. (b) Photic zone euxinic conditions in the corresponding water column and associated microorganisms and organic matter sources with their molecular indicators relevant for this study. PZE = photic zone euxinia, $\mathrm{SRB}=$ sulfate reducing bacteria, $\mathrm{MTTC}=$ methyltrimethyltridecylchromans. Water column stratification and PZE are evident in the abundance of gammacerane and Chlorobi carotenoid derivatives (e.g. isorenieratane), respectively. Higher plant input was indicated by the abundance of perylene, MTTCs and palynological analysis. (c) Proposed mechanism of chroman formation ( $L i$ et al. 1995) from predominantly phytoplankton derived phytol with higher plant phenols during early diagenesis.

\subsubsection{Gammacerane index as indicator of water column stratification}

Gammacerane was initially associated with hypersaline paleoenvironments but more recently has been established as marker for water-column stratification (e.g. tenHaven et al., 1989; Harvey and McManus, 1991; Sinninghe Damsté et al., 1995). This triterpenoid originates from bacteriovorous ciliates grazing on microbes at the oxic-anoxic interface of a stratified water-column (Sinninghe Damsté et al., 1995). Therefore the enhanced gammacerane indices 
observed here indicate the presence of microbial communities (possibly biofilms or microbial mats) which grew at the stable oxic-anoxic interface between epi- and hypolimnion, and contained organisms such as Chlorobi. The gammacerane precursor tetrahymanol (IV) has also been found in the oxygen minimum zone of the water column in the present-day Black Sea (Wakeham et al., 2007).

\subsubsection{Evidence of anoxia and euxinia}

The enhanced activity of sulfate reducing bacteria (SRB) under anoxic conditions and the resulting production of hydrogen sulfide is evident in a suite of ${ }^{13} \mathrm{C}$-enriched Chlorobi carotenoid derivatives, including intact paleo (XI)- and isorenieratane I, (Figure A3 and Table 1), representing unequivocal evidence of paleoenvironmental euxinia extending to the photic zone (PZE). The significant ${ }^{34} \mathrm{~S}$-depletion of sedimentary pyrite $\left(\delta^{34} \mathrm{~S}:-11.9\right.$ to $-24.0 \%$; Table 1$)$ relative to the estimated value of Devonian seawater sulfate between $\sim 15$ and $20 \%$ o (Kampschulte and Strauss, 2004) indicates that bacterial sulfate reduction was not significantly limited by dissolved sulfate and occurred under essentially open conditions in surface sediments or the water column (Meyer and Kump, 2008). The measured data are in the same range reported

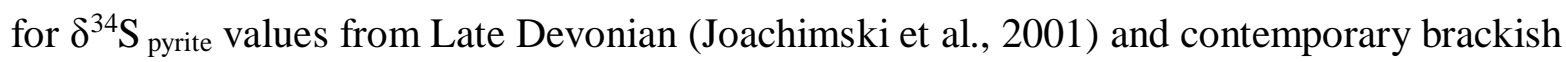

Baltic Sea sediments (Böttcher and Lepland, 2000), but less ${ }^{34} S$-depleted compared to $\delta^{34} S_{\text {pyrite }}$ values of the modern brackish Black Sea (Neretin et al., 2004). For a further discussion about $\delta^{34} \mathrm{~S}$ values refer to Tulipani et al. (2014).

Euxinic palaeoenvironmental conditions are also consistent with low C/S ratios between 0.1 and 0.5 (Table 1), which show a significant excess of reduced sulfur compared to modern marine sediments (Raiswell and Berner, 1987). Furthermore, relatively low $\delta^{13} \mathrm{C}$ values of carbonate, OM and biomarkers (Tables 1 and A1) indicate enhanced recycling of $\mathrm{OM}$ in 
sediments and the lower water column, presumably by anaerobic SRB (Küspert, 1982; Tulipani et al., 2014).

Anoxic conditions in the investigated depositional environment are also evident in the low $\mathrm{Pr} / \mathrm{Ph}$ ratios. $\mathrm{Pr} / \mathrm{Ph}$ is a frequently used paleoredox indicator (e.g. Didyk et al., 1978; Peters et al. 2005) based on the preferential formation of phytane (X) over pristane (IX) from the phytol side-chain of different chlorophyll- $a$ (XII) under anoxic conditions (Brooks et al., 1969). However, it can also be influenced by other plaeoenvironmental conditions such as salinity (ten Haven et al., 1985; Schwark et al., 1998) or pristane (IX) generation during thermal maturation (Goossens et al., 1984; Li et al., 1995; Frimmel et al., 2004). Nevertheless, in this case it seems to represent a reliable indicator for anoxia as it is used in combination with other parameters including the abundance of Chlorobi carotenoid derivatives and the enhanced gammacerane indices.

\subsubsection{Perylene as indicator of terrigenous input}

The presence of perylene (VIII) is an indicator for terrigenous input. Unlike other unsubstituted PAHs which are predominantly pyrogenic, perylene (VIII) forms via diagenetic processes under anoxic conditions (e.g. Aizenshtat, 1973; Orr and Grady, 1967; Fernández et al., 1996; Wakeham et al., 1980; Grice et al., 2009; Jiang et al., 2000; Suzuki et al., 2010). Perylene most likely originates from quinone pigments which are present in wood degrading fungi and some other organisms including crinoids and some insects (Grice et al., 2009; Suzuki et al., 2010). It occurs frequently in sediments and crude oils dating back to the Mesozoic (Blumer, 1960; Orr and Grady, 1967; Aizenshtat, 1973; Laflamme and Hites, 1978; Wakeham et al., 1979, 1980) but has only occasionally been reported in older sediments (Grice et al., 2009; Shan-Tan 
and Kaplan, 1992) and appears to be largely absent before the expansion of vascular plants and in marine sourced oils (Grice et al., 2009).

Whilst an origin from quinone pigments in marine fungi (mainly lignin degraders) or crinoids cannot be excluded, its abundance in the Devonian samples observed here, which coincides with the evolution of the first woody plants and formation of forests (Meyer-Berthaud et al., 2010), points to a likely terrigenous source. Higher plant input was additionally confirmed by palynological and other microscopic evidence which included comminuted plant debris, resin bodies and microfossils from progymnosperms (see Tulipani et al., (2014)). Other PAHs with a presumably pyrogenic origin (e.g. benzo $[a]$ pyrene, benzo[ $e]$ pyrene, coronene, fluoranthenes and pyrenes) were also present at low concentrations and might indicate input from bushfire material which was likely transported to the site as airborne particles. However, their abundance profiles did not show any correlation with perylene and MTTC (V) abundance or chroman ratios (Tulipani et al. 2014).

\subsubsection{Significance of terrigenous input}

The terrigenous nutrient input, which likely occurred or intensified seasonally with freshwater inflow, contributed to enhanced phytoplanktonic productivity (and degradation of organic debris) that resulted in the development of oxygen deficiency and PZE in the hypolimnion due to the limited vertical water circulation. However, the relatively low TOC contents, despite a low thermal maturity (Tables 1 and A1) and excellent conditions for OM preservation, seem to be contradicting the high productivity environment indicated by the previously described molecular parameters. It seems feasible that the persistently stratified water column lead to the development of anoxia in the hypolimnion even in an oligotrophic paleoenvironmental with some terrigenous nutrient input. This is consistent with the location of 
the Middle to Late Devonian Canning Basin in a hot arid subequatorial belt at a paleolatitude of $\sim 15{ }^{\circ} \mathrm{S}$ (Scotese and McKerrow, 1990). Furthermore, intense carbonate precipitation (see carbonate $\%$ in Table 1) may have diluted the TOC \% in some core sections.

The low TOC \% could, however, also indicate that high terrigenous nutrient input and algal blooms were only episodic or even seasonal (Tulipani et al. 2014). It is possible that initially high amounts of sedimentary OM deposited in the previously described paleoenvironment were diminished during alternating periods of oxic conditions, and that only a small proportion of the OM was well-preserved for example by early encapsulation carbonate cements.

\subsection{Origin of Pristane and Phytane}

The most common source of sedimentary pristane (IX) and phytane $(\mathbf{X})$ is the phytol side chain in chlorophyll- $a$ (XII), which in the marine setting described here, would typically be provided by phytoplankton, likely supplemented to an unknown extent with additional terrestrial plant input (Hayes et al., 1990). However, there are also other potential pristane (IX) and phytane (X) sources including archaea (Rowland and Robson, 1990; Grice et al., 1998b), and pristane (IX) may be generated during thermal maturation from chromans (Li et al., 1995; Frimmel et al., 2004; Tulipani et al., 2013) or tocopherols (Goossens et al., 1984). The latter likely did not significantly alter $\mathrm{Pr} / \mathrm{Ph}$ ratios reported here due to the exceptionally low thermal maturity of the samples (see Table 1 and A1 as well as Tulipani et al., 2014). Similar and relatively depleted $\delta^{13} \mathrm{C}$ values measured for pristane $(\mathbf{I X})$ and phytane $(\mathbf{X})$ in this sample suite (Table 1) point towards common algal, cyanobacterial or higher plant sources. $\delta^{13} \mathrm{C}$ values of short chain $n$-alkanes $\left(\mathrm{C}_{19}\right.$ to $\left.\mathrm{C}_{21}\right)$ were in the same range or slightly more enriched in comparison to the isoprenoids (Table 1 ), indicating a mixed $n$-alkanes source from 
phytoplankton and heterotrophic bacteria (Schouten et al., 1998; Grice et al., 2005). However, it has to be noted that this interpretation is limited because $\delta^{13} \mathrm{C}$ values of pristane (IX) have been determined only in two samples.

\subsection{Origin and Significance of MTTCs}

The chroman ratio (see introduction for definition) seems to be a reliable paleosalinity indicator based upon empirical studies and comparison with other inorganic and molecular parameters (e.g. Sinninghe Damsté et al., 1987, 1993; Schwark and Püttmann, 1990; Grice et al., 1998c; Schwark et al., 1998, Wang et al., 2011). Nevertheless, an elucidation of the origin and formation pathway of MTTCs (V) would possibly help to utilize these compounds more accurately as paleosalinity indicators (e.g. in a stratified water-column) and may also broaden the field of MTTC (V) applications in paleoenvironmental reconstructions, particularly regarding a potential relation to terrigenous input or freshwater incursions. The chroman ratio does not seem to be affected by thermal maturation over a wide temperature range, as indicated in artificial maturation experiments by Koopmans et al., (1996b,1998). However, the overall MTTC (V) concentration increased during artificial maturation (Koopmans et al., 1996b) and there also is some indication for a relationship between the ratio of the 5,8- to the 7,8-dimethyl MTTC and thermal maturity, particularly in very immature samples (Bao et al. 2009).

MTTCs (V) have been found almost exclusively in geological samples post-dating the evolution of vascular plants, mainly in samples of Permian age or younger (Sinninghe Damsté et al., 1987) but also occasionally in Middle to Late Devonian sediments (Marynowski and Filipiak, 2007; Racka et al., 2010), which would be consistent with an origin from condensation reactions involving higher plant-derived alkylphenols (Li et al., 1995; Figure 1). However, they have also once been reported in Neoproterozoic/Early Cambrian crude oils (Dutta et al., 2013) which could 
be explained by a different source of alkylphenols, - i.e. from algal-derived macromolecular structures or, possibly, some bacteria (Reusch and Sadoff, 1979; Sabelle et al., 1993; Li and Larter, 1995).

Figure 2 illustrates correlations of MTTC parameters with other molecular indicators throughout the analyzed sections of the MR-1 core. The chroman ratio exhibited a strongly inverse relationship $\left(\mathrm{R}^{2}=0.97\right)$ with $\mathrm{Pr} / \mathrm{Ph}$ (Figure $\left.2 \mathrm{a}\right)$. This is contrary to previous studies of presumably more open marine settings which showed a positive correlation, attributed to the mutual salinity dependency of both ratios (higher salinity leading to lower chroman and $\operatorname{Pr} / \mathrm{Ph}$ ratios (Schwark et al., 1998, Wang et al., 2011)). In a study by Bao et al. (2009) no correlation between these parameters was evident. The inverse correlation we observed in sediments deposited from a stratified water column indicates that chroman ratios reflect salinity in the upper water layer whereas $\mathrm{Pr} / \mathrm{Ph}$ seems to be influenced by the conditions in the lower water column or sediments (i.e. higher salinity and anoxia (e.g. Didyk et al., 1978; Schwark et al., 1998)). This is consistent with previous suggestions of chroman formation in the upper water column (Sinninghe Damsté et al., 1993). A low salinity in the epilimnion (high chroman ratios) correlates with more persistent stratification and hence anoxia and higher salinities in the hypolimnion and sediments (low $\mathrm{Pr} / \mathrm{Ph}$ ratios).

Further evidence for this comes from the sharp increase of the gammacerane index in samples with higher chroman ratios (Figure 2b). The concentration of sedimentary gammacerane (III) is largely determined by (i) the persistence of stratification over time and (ii) the abundance of Chlorobi and Chromatiaceae, the main food source of bacterivorous ciliates at the chemocline. The positive correlation between these parameters reflects the interdependency of salinity levels in the upper water layer (reflected in chroman ratios) and persistence of stratification. The trophic link between ciliates and Chlorobi together with the promotion of PZE 
by water column stratification account for the co-occurrence of high gammacerane indices (Figure 2b) and abundant Chlorobi biomarkers (e.g. paleorenieratane, XI; Figure 2d). The presence of these microbial communities may have been involved in the enhancement of early diagenetic reactions in the water column such as MTTC $(\mathbf{V})$ formation from condensation reactions.

Covariance between 5,7,8 trimethyl-MTTC (triMeMTTC) and perylene (VIII) concentrations (Figure 2c) might represent a link to similar higher plant sources, also supporting a diagenetic formation of MTTCs (V) from alkyl phenols reacting with phytol (Figure 1c). Reducing conditions favoring perylene (VIII) preservation were stabilized by fresh surface waters hindering vertical water mixing. The similar $\delta^{13} \mathrm{C}$ values of phytane $(\mathbf{X})$ and triMeMTTC observed here (Figure 2e), and generally similar $\delta^{13} \mathrm{C}$ values of pristane $(\mathbf{I X})$, phytane $(\mathbf{X})$ and MTTCs (V) reported in several previous studies (van Kaam-Peters et al., 1997; Grice et al., 1998a, 1998c; Hong et al., 2007) concur with a common phytol source of pristane (IX), phytane (X) and the isoprenoidal subunit of MTTCs (V). The latter largely influences the stable isotopic composition of the whole molecule due to its larger size compared to the phenolic moiety. However, such an isotopic relationship would also be expected for a direct origin of phytol and MTTCs (V) from similar phytoplanktonic source organisms as suggested by Sinninghe Damsté et al. (1993). To further investigate potentially different sources of the phenolic and isoprenoidal subunits in MTTCs (V) it would be useful to separately measure the $\delta^{13} \mathrm{C}$ of these distinct moieties, which might be possible by pyrolysis-GC-irMS (Tulipani et al., 2013). 

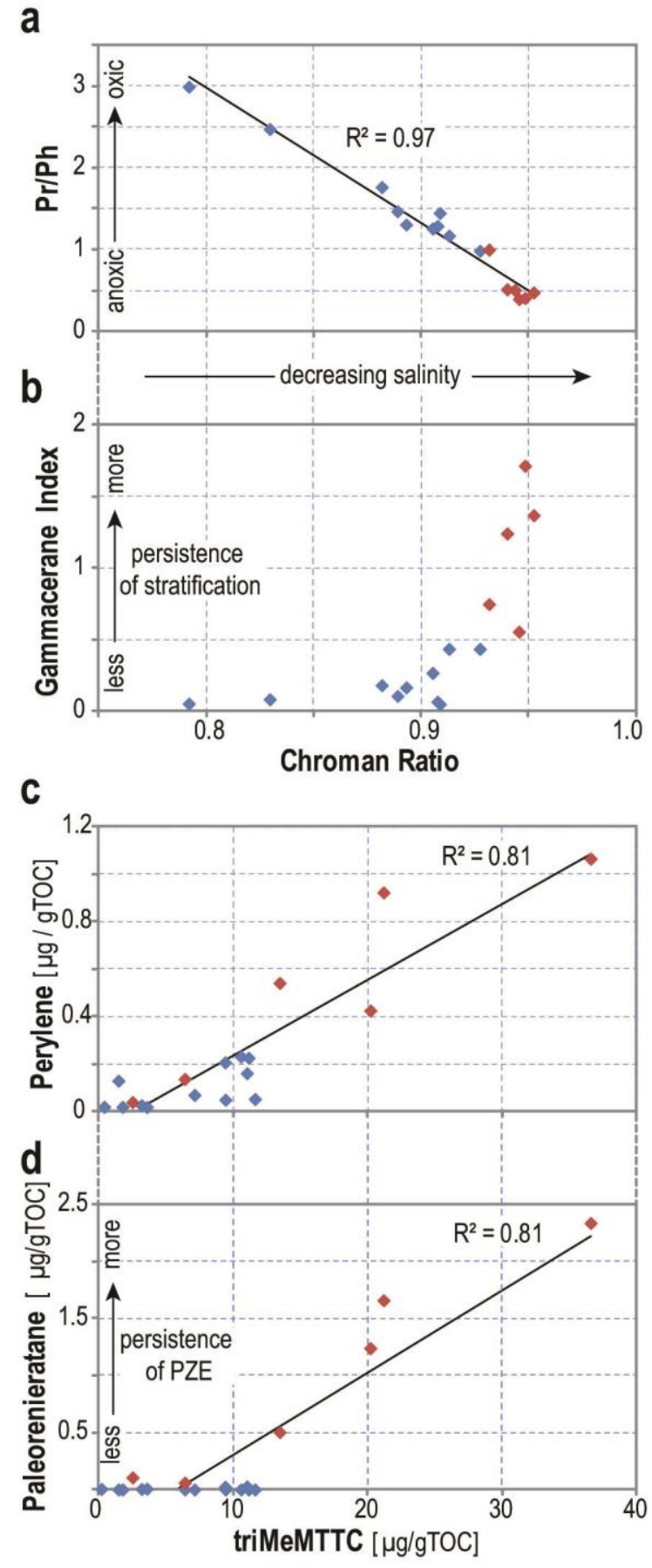

e

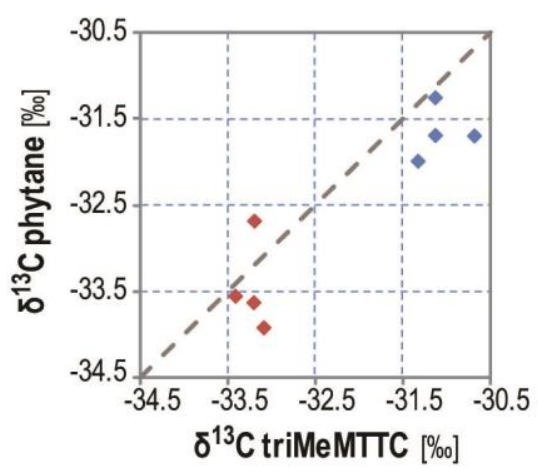

Figure 2: Co-variation of characteristic methyltrimethyltridecylchroman (MTTC) parameters with other biomarkers. triMeMTTC $=5,7,8$ trimethyl-MTTC, chroman ratio $=$ triMeMTTC/Total MTTCs, $\mathrm{Pr} / \mathrm{Ph}=$ pristane/phytane, $\mathrm{PZE}=$ photic zone euxinia, gammacerane index $=$ gammacerane (III) $/ 17 \alpha, 21 \beta$-hopane (VII). Red diamonds represent sediments deposited in the Late Givetian-Early Frasnian in a stratified, anoxic and euxinic paleoenvironment whereas blue diamonds represent overlying sediments deposited later in the Frasnian in a less restricted setting. The chroman ratio is an established paleosalinity indicator with values $<0.5$ reflecting hypersaline and values $>0.6$ normal marine or freshwater conditions (Sinninghe Damsté et al., 1993). However, the taphonomic processes are unclear. The relative ${ }^{13} \mathrm{C}$ depletion of phytane $(\mathbf{X})$ and triMeMTTC in the older samples (e) are consistent with $\delta^{13} \mathrm{C}$ trends of bulk $\mathrm{OM}$ and carbonates (Table S1) and could represent enhanced recycling of ${ }^{12} \mathrm{C}$-rich $\mathrm{OM}$ by $\mathrm{SRB}$ in the anoxic environments [Küspert, 1982]. 


\section{Conclusions and outlook}

We demonstrate that chroman ratios in the analyzed Middle to Late Devonian sediments were controlled by low salinities in the upper water column. Physicochemical properties between epi- and hypolimnion differed strongly, minimizing vertical mixing of the water body and favoring growth of microbial communities at the interface layer. Grazing of these organisms by bacteriovorous ciliates is indicated by the presence of gammacerane (III) and confirmed by strong correlations with other biomarker parameters indicating reducing and euxinic conditions in the hypolimnion. The covariance of triMeMTTC abundance with perylene (VIII) indicates that MTTCs (V) might be representative of terrigenous/higher plant sources which are consistent with a diagenetic formation from condensation reactions of higher plant derived alkylphenols with phytol. The molecular approach presented here is of high interest because water column stratification and related anoxia are important factors in OM preservation and often related to biological crises or mass extinction events.

The general lack of suitable indicators for water column stratification may have led to an underestimation of freshwater-induced stratification and nutrient supply, both favoring organic matter production and exceptional preservation. MTTC-based studies provide a useful means to test the hypothesis of freshwater-induced stratification in oceanic anoxia and euxinia development.

\section{Acknowledgments}

ST thanks Curtin University for providing a Curtin Strategic International Research Scholarship (CSIRS) and the Institute for Geoscience Research (TIGeR) for a top-up scholarship. KG acknowledges the Australian Research Council (ARC) for a Discovery QEII and ARC DORA grant supporting this research, and the John de Laeter Center for Isotope 
Research and ARC LIEF grants which provided the infrastructure support. Chevron (Ted Playton), the Geological Survey of Western Australia and the Minerals and Energy Research Institute of Western Australia (M396) are thanked for sponsoring an ARC Linkage grant (LP0883812) which supported the fieldwork and research. Research at MIT was supported by a grant from the NASA Astrobiology Institute. Geoff Chidlow and Stephen Clayton are acknowledged for technical support with GC-MS and GC-irMS analysis. Wundargoodie, Mimbi Community, and Mount Pierre Station are thanked for supporting the field work. MEB wishes to thank P. Escher and I. Scherff for analytical support. CBF publishes with the permission of the CEO of Geoscience Australia. Joseph Curiale and an unknown reviewer are thanked for constructive comments.

\section{References}

Aizenshtat, Z., 1973. Perylene and its geochemical significance. Geochimica et Cosmochimica Acta 37, 559-567, doi: 10.1016/0016-7037(73)90218-4

Algeo, T.J., Berner, R.A., Maynard, J.B., Scheckler, S.E., 1995. Late Devonian oceanic anoxic events and biotic crises:"rooted" in the evolution of vascular land plants? GSA Today, 5(3), 64-66.

Algeo, T.J., Scheckler, S.E., Maynard, J.B., 2001. Effects of the Middle to Late Devonian spread of vascular land plants on weathering regimes, marine biotas, and global climate, in Plants invade the land: Evolutionary and environmental perspectives, edited by P. Gensel and D. Edwards, pp. 213-236, Columbia University Press.

Algeo, T.J., Scheckler, S.E., 2010. Land plant evolution and weathering rate changes in the Devonian. Journal of Earth Science, 21, 75-78, doi:10.1007/s12583-010-0173-2. 
Bao, J., Zhu, C., Ma, A., 2009. The relationship between methylated chromans and maturity of organic matter in the source rocks from Jianghan hypersaline basin. Science in China Series D-Earth Sciences 52, 34-41, doi: 10.1007/s11430-009-5018-4

Barakat, A., Rullkötter, J., 1997. A comparative study of molecular paleosalinity indicators: chromans, tocopherols and $\mathrm{C}_{20}$ isoprenoid thiophenes in miocene lake sediments (Nördlinger Ries, southern Germany). Aquatic Geochemistry, 3(2), 169-190, doi:10.1023/a:1009645510876.

Blumer, M., 1960. Pigments of a Fossil Echinoderm. Nature 188, 1100-1101, doi:10.1038/1881100b0

Böttcher, M.E., Lepland, A., 2000 Biogeochemistry of sulfur in a sediment core from the westcentral Baltic Sea: Evidence from stable isotopes and pyrite textures. Journal of Marine Systems, 25(3-4), 299-312, doi: http://dx.doi.org/10.1016/S0924-7963(00)00023-3.

Brooks, J.D., Gould, K., Smith, J.W., 1969. Isoprenoid hydrocarbons in coal and petroleum. Nature 222, 257-259.

Didyk, B.M., Simoneit, B.R.T., Brassell, S.C., Eglinton, G., 1978. Organic geochemical indicators of palaeoenvironmental conditions of sedimentation. Nature, 272(5650), 216-222.

Dutta, S., Bhattacharya, S., Raju, S.V., 2013. Biomarker signatures from Neoproterozoic-Early Cambrian oil, western India, Organic Geochemistry, 56(0), 68-80, doi:http://dx.doi.org/10.1016/j.orggeochem.2012.12.007.

Fernández P., Vilanova, R., Grimalt, J.O., 1996. PAH distributions in sediments from high mountain lakes. Polycyclic Aromatic Compounds, 9, 121-128, doi:10.1080/10406639608031209 
Fossing, H., Jørgensen, B., 1989. Measurement of bacterial sulfate reduction in sediments: Evaluation of a single-step chromium reduction method. Biogeochemistry, 8(3), 205-222, doi: $10.1007 / b f 00002889$.

Frimmel, A., Oschmann, W., Schwark, L., 2004. Chemostratigraphy of the Posidonia Black Shale, SW Germany: I. Influence of sea-level variation on organic facies evolution. Chemical Geology, 206(3-4), 199-230, doi:http://dx.doi.org/10.1016/j.chemgeo.2003.12.007.

Goossens, H., de Leeuw, J.W., Schenck, P.A., Brassell, S.C., 1984. Tocopherols as likely precursors of pristane in ancient sediments and crude oils. Nature. 312(5993), 440-442.

Grice, K., Schouten, S., Peters, K.E., Sinninghe Damsté J.S., 1998a. Molecular isotopic characterisation of hydrocarbon biomarkers in Palaeocene-Eocene evaporitic, lacustrine source rocks from the Jianghan Basin, China. Organic Geochemistry ,29(5-7), 1745-1764, doi:http://dx.doi.org/10.1016/S0146-6380(98)00075-8.

Grice, K., Schouten, S., Nissenbaum, A., Charrach, J., Sinninghe Damsté, J.S., 1998b. Isotopically heavy carbon in the $\mathrm{C}_{21}$ to $\mathrm{C}_{25}$ regular isoprenoids in halite-rich deposits from the Sdom Formation, Dead Sea Basin, Israel. Organic Geochemistry, 28(6), 349-359, doi:10.1016/s0146-6380(98)00006-0.

Grice, K., Schouten, S., Nissenbaum, A., Charrach, J., Sinninghe Damsté, J.S., 1998c. A remarkable paradox: Sulfurised freshwater algal (Botryococcus braunii) lipids in an ancient hypersaline euxinic ecosystem. Organic Geochemistry, 28(3-4), 195-216, doi:http://dx.doi.org/10.1016/S0146-6380(97)00127-7.

Grice, K., Cao, C., Love, G.D., Böttcher, M.E., Twitchett, R.J., Grosjean, E., Summons, R.E., Turgeon, S.C., Dunning, W., Jin, Y., 2005. Photic zone euxinia during the Permian-Triassic superanoxic event. Science, 307(5710), 706-709, doi:10.1126/science.1104323. 
Grice, K., Lu, H., Atahan, P., Asif, M., Hallmann, C., Greenwood, P., Maslen, E., Tulipani, S., Williford, K., Dodson, J., 2009. New insights into the origin of perylene in geological samples. Geochimica et Cosmochimica Acta, 73(21), 6531-6543, doi:10.1016/j.gca.2009.07.029.

Hartgers, W.A., Sinninghe Damsté, J.S., Requejo, A.G., Allan, J., Hayes, J.M., Ling, Y., Xie, T.M., Primack, J., de Leeuw, J.W., 1994. A molecular and carbon isotopic study towards the origin and diagenetic fate of diaromatic carotenoids. Organic Geochemistry, 22(3-5), 703725. doi: http://dx.doi.org/10.1016/0146-6380(94)90134-1

Harvey, H.R., McManus G.B., 1991. Marine ciliates as a widespread source of tetrahymanol and hopan-3 $\beta$-ol in sediments. Geochimica et Cosmochimica Acta, 55(11), 3387-3390, doi:http://dx.doi.org/10.1016/0016-7037(91)90496-R.

Hayes, J.M., Freeman, K.H., Popp, B.N., Hoham, C.H., 1990. Compound-specific isotopic analyses: A novel tool for reconstruction of ancient biogeochemical processes. Organic Geochemistry, 16(4-6), 1115-1128, doi:http://dx.doi.org/10.1016/0146-6380(90)90147-R.

Hong, L.U., Linhui, H.O.U., Tengshui, C., Ping'an, P., Guoying, S., 2007. Stable carbon isotopic compositions of methylated-MTTC in crude oils from saline lacustrine depositional environment: source implications. Acta Geologica Sinica - English Edition, 81(6), 10411048, doi:10.1111/j.1755-6724.2007.tb01027.x.

Jaraula, C.M.B., Grice, K., Twitchett, R.J., Böttcher, M.E., LeMetayer, P., Dastidar, A.G., Opazo L.F., 2013. Elevated $p \mathrm{CO}_{2}$ leading to Late Triassic extinction, persistent photic zone euxinia and rising sea levels. Geology, 41(9), 955-958, doi:10.1130/g34183.1.

Joachimski, M.M., Ostertag-Henning, C., Pancost, R.D., Strauss, H., Freeman, K.H., Littke, R., Sinninghe Damsté, J.S., Racki, G., 2001. Water column anoxia, enhanced productivity and concomitant changes in $\delta^{13} \mathrm{C}$ and $\delta^{34} \mathrm{~S}$ across the Frasnian-Famennian boundary (Kowala- 
Holy Cross Mountains/Poland), Chemical Geology, 175(1-2), 109-131, doi:http://dx.doi.org/10.1016/S0009-2541(00)00365-X.

Joachimski, M.M., Breisig, S., Buggisch, W., Talent, J.A., Mawson, R., Gereke, M., Morrow, J.R., Day, J., Weddige, K., 2009. Devonian climate and reef evolution: Insights from oxygen isotopes in apatite. Earth and Planetary Science Letters, 284(3-4), 599-609, doi: http://dx.doi.org/10.1016/j.eps1.2009.05.028.

Johnson, J.G., Klapper, G., Sandberg, C.A., 1985. Devonian eustatic fluctuations in Euramerica. Geological Society of America Bulletin, 96(5), 567-587, doi:10.1130/00167606(1985)96<567:defie>2.0.co;2.

Kampschulte, A., Strauss, H., 2004. The sulfur isotopic evolution of Phanerozoic seawater based on the analysis of structurally substituted sulfate in carbonates. Chemical Geology, 204(34), 255-286, doi:http://dx.doi.org/10.1016/j.chemgeo.2003.11.013.

Koopmans, M.P., Schouten, S., Kohnen, M.E.L., Sinninghe Damsté, J.S., 1996a. Restricted utility of aryl isoprenoids as indicators for photic zone anoxia. Geochimica et Cosmochimica Acta, 60(23), 4873-4876, doi: http://dx.doi.org/10.1016/S0016-7037(96)00303-1.

Koopmans, M.P., De Leeuw, J.W., Lewan, M.D., Sinninghe Damste, J.S., 1996b. Impact of diaand catagenesis on sulphur and oxygen sequestration of biomarkers as revealed by artificial maturation of an immature sedimentary rock. Organic Geochemistry 25, 391-426.

Koopmans, M.P., Rijpstra, W.I.C., de Leeuw, J.W., Lewan, M.D., Sinninghe Damsté, J.S., 1998. Artificial maturation of an immature sulfur- and organic matter-rich limestone from the Ghareb Formation, Jordan. Organic Geochemistry 28, 503-521, doi:http://dx.doi.org/10.1016/S0146-6380(98)00015-1 
Küspert, W., 1982. Environmental changes during oil shale deposition as deduced from stable isotope ratios, in Cyclic and Event Stratification, edited by G. Einsele and A. Seilacher, pp. 482-501, Springer, Berlin.

Li, M., Larter, S.R., 1995. Reply to comments by Sinninghe Damsté and De Leeuw (1995) on Li et al. (1995), Organic Geochemistry 23, 159-167. Organic Geochemistry, 23(11-12), 10891093, doi:http://dx.doi.org/10.1016/0146-6380(95)90084-5.

Li, M., Larter, S.R., Taylor, P., Jones, D.M., Bowler, B., Bjorøy, M., 1995. Biomarkers or not biomarkers? A new hypothesis for the origin of pristane involving derivation from methyltrimethyltridecylchromans (MTTCs) formed during diagenesis from chlorophyll and alkylphenols. Organic Geochemistry, 23(2), 159-167, doi:http://dx.doi.org/10.1016/01466380(94)00112-E.

Laflamme, R.E., Hites, R.A., 1978. The global distribution of polycyclic aromatic hydrocarbons in recent sediments. Geochimica et Cosmochimica Acta 42, 289-303, doi: 10.1016/00167037(78)90182-5.

Long, J.A., Trinajstic, K., 2010. The Late Devonian Gogo Formation lägerstatte of Western Australia: exceptional early vertebrate preservation and diversity. Annual Review of Earth and Planetary Sciences, 38(1), 255-279, doi:10.1146/annurev-earth-040809-152416.

Mann, J.L., Vocke, R.D., Kelly, W.R., 2009. Revised $\delta^{34}$ S reference values for IAEA sulfur isotope reference materials S-2 and S-3. Rapid Communications in Mass Spectrometry, 23(8), 1116-1124, doi:10.1002/rcm.3977.

Marynowski, L., Filipiak, P., 2007. Water column euxinia and wildfire evidence during deposition of the Upper Famennian Hangenberg event horizon from the Holy Cross Mountains (central Poland). Geological Magazine, 144(3), 569-595. 
McGregor, D.C., Playford, G., 1993. Canadian and Australian Devonian spores: zonation and correlation. Bulletin of the Geological Survey of Canada, v. 438, 125p. (imprinted 1992), $438,125$.

Melendez, I., Grice, K., Schwark, L., 2013a. Exceptional preservation of Palaeozoic steroids in a diagenetic continuum. Science Reports, 3, doi:10.1038/srep02768http://www.nature.com/srep/2013/130926/srep02768/abs/srep02768. html\#supplementary-information.

Melendez, I., Grice, K., Trinajstic, K., Ladjavardi, M., Greenwood, P., Thompson, K., 2013b. Biomarkers reveal the role of photic zone euxinia in exceptional fossil preservation: An organic geochemical perspective. Geology, 41(2), 123-126, doi:10.1130/G33492.1.

Meyer-Berthaud, B., Soria, A., Decombeix, A.L., 2010. The land plant cover in the Devonian: a reassessment of the evolution of the tree habit. Geological Society, London, Special Publications, 339(1), 59-70, doi:10.1144/sp339.6.

Meyer, K.M., Kump, L.R., 2008. Oceanic euxinia in Earth history: causes and consequences. Annual Review of Earth and Planetary Sciences, 36(1), 251-288, doi:10.1146/annurev.earth.36.031207.124256.

Mintz, J.S., Driese, S.G., White, J.D., 2010. Environmental and ecological variability of Middle Devonian (Givetian) forests in appalachian basin paleosols, New York, United States, Palaios, 25(2), 85-96, doi:10.2110/palo.2009.p09-086r.

Murray, J.W., Stewart, K., Kassakian, S., Krynytzky, M., DiJulio, D., 2007. Oxic, suboxic, and anoxic conditions in the Black Sea, in The Black Sea flood question, changes in coastline, climate and human settlement, edited by V. Yanko-Hombach, A. S. Gilbert, N. Panin and P. M. Dolukhanow, Springer, Dordrecht. 
Neretin, L.N., Böttcher, M.E., Jørgensen, B.B., Volkov, I.I., Lüschen, H., Hilgenfeldt, K., 2004. Pyritization processes and greigite formation in the advancing sulfidization front in the upper Pleistocene sediments of the Black Sea. Geochimica et Cosmochimica Acta, 68(9), 2081-2093, doi:http://dx.doi.org/10.1016/S0016-7037(03)00450-2.

Orr W.L., Grady, J.R., 1967. Perylene in basin sediments off southern california. Geochimica et Cosmochimica Acta 31, 1201-1209, doi: 10.1016/s0016-7037(67)80058-9.

Paul, D., Skrzypek. G., 2007. Assessment of carbonate-phosphoric acid analytical technique performed using GasBench II in continuous flow isotope ratio mass spectrometry. International Journal of Mass Spectrometry, 262(3), 180-186, doi:http://dx.doi.org/10.1016/j.ijms.2006.11.006.

Peters, K.E., Walters, C.C., Moldowan, J.M., 2005. The biomarker guide: Interpreting molecular fossils in petroleum and ancient sediments. Prentice-Hall, New Jersey.

Playford, P.E., Hocking, R.M., Cockbain, A.E., 2009. Devonian reef complexes of the Canning Basin, Western Australia, Geological Survey of Western Australia, Bulletin 145, 444p.

Racka, M., Marynowski, L., Filipiak, P., Sobstel, M., Pisarzowska, A., Bond, D.P.G., 2010. Anoxic annulata events in the Late Famennian of the Holy Cross Mountains (southern Poland): geochemical and palaeontological record. Palaeogeography, Palaeoclimatology, Palaeoecology, 297(3-4), 549-575, dio: http://dx.doi.org/10.1016/j.palaeo.2010.08.028. Raiswell, R., Berner, R.A., 1987. Organic carbon losses during burial and thermal maturation of normal marine shales. Geology, 853-856. http://dx.doi.org/10.1130/00917613(1987)15b853:ocldbaN2.0.co;2.

Reusch, R.N., Sadoff, H.L., 1979. 5-n-Alkylresorcinols from encysting Azotobacter vinelandii: isolation and characterization, Journal of Bacteriology, 139(2), 448-453. 
Rowland, S.J., Robson, J.N., 1990. The widespread occurrence of highly branched acyclic $\mathrm{C}_{20}$, $\mathrm{C}_{25}$ and $\mathrm{C}_{30}$ hydrocarbons in recent sediments and biota- $\mathrm{A}$ review. Marine Environmental Research, 30(3), 191-216, doi:10.1016/0141-1136(90)90019-k.

Sabelle, S., Oliver, E., Metzger, P., Derenne, S., Largeau, C., 1993. Variability in phenol moieties in the resistant biomacromolecules of the A and B races of Botryococcus braunii. Geochemical implications, paper presented at Organic Geochemistry, Poster sessions from the 16th International Meeting on Organic Geochemistry. Falch Hurtigtrykk, Oslo.

Schouten, S., Klein Breteler, W.C.M., Blokker, P., Schogt, N., Rijpstra, W.I.C., Grice, K., Baas, M., Sinninghe Damsté, J.S., 1998. Biosynthetic effects on the stable carbon isotopic compositions of algal lipids: implications for deciphering the carbon isotopic biomarker record. Geochimica et Cosmochimica Acta, 62(8), 1397-1406, doi:http://dx.doi.org/10.1016/S0016-7037(98)00076-3.

Schwark, L., Püttmann, W., 1990. Aromatic hydrocarbon composition of the Permian Kupferschiefer in the Lower Rhine Basin, NW Germany. Organic Geochemistry, 16(4-6), 749-761, doi:http://dx.doi.org/10.1016/0146-6380(90)90114-F.

Schwark, L., Vliex, M., Schaeffer, P., 1998. Geochemical characterization of Malm Zeta laminated carbonates from the Franconian Alb, SW-Germany (II). Organic Geochemistry, 29(8), 1921-1952.

Scotese, C.R., McKerrow, W.S., 1990. Revised World maps and introduction. Geological Society, London, Memoirs, 12(1), 1-21, doi:10.1144/gsl.mem.1990.012.01.01.

Sinninghe Damsté, J.S., De Leeuw, J.W., 1995. Comments on "Biomarkers or not biomarkers. A new hypothesis for the origin of pristane involving derivation from methyltrimethyltridecylchromans (MTTCs) formed during diagenesis from chlorophyll and alkylphenols" from M. Li, S.R. Larter, P. Taylor, D.M. Jones, B. Bowler and M. Bjorøy. 
Organic Geochemistry, 23(11-12), 1085-1087, doi:http://dx.doi.org/10.1016/01466380(95)00092-5.

Sinninghe Damsté, J.S., Kock-Van Dalen, A.C., De Leeuw, J.W., Schenck, P.A., Guoying, S., Brassell, S.C., 1987. The identification of mono-, di- and trimethyl 2-methyl-2-(4,8,12trimethyltridecyl)chromans and their occurrence in the geosphere. Geochimica et Cosmochimica Acta, 51(9), 2393-2400, doi:http://dx.doi.org/10.1016/0016-7037(87)902924.

Sinninghe Damsté, J.S., Keely, B.J., Betts, S.E., Baas, M., Maxwell, J.R., de Leeuw, J.W., 1993. Variations in abundances and distributions of isoprenoid chromans and long-chain alkylbenzenes in sediments of the Mulhouse Basin: a molecular sedimentary record of palaeosalinity. Organic Geochemistry, 20(8), 1201-1215, doi:http://dx.doi.org/10.1016/0146-6380(93)90009-Z.

Sinninghe Damsté, J.S., Kenig, F., Koopmans, M.P., Köster, J., Schouten, S., Hayes, J.M., de Leeuw, J.W., 1995. Evidence for gammacerane as an indicator of water column stratification. Geochimica et Cosmochimica Acta, 59(9), 1895-1900, doi:http://dx.doi.org/10.1016/0016-7037(95)00073-9.

Skrzypek, G., Paul, D., 2006. $\delta^{13} \mathrm{C}$ analyses of calcium carbonate: comparison between the GasBench and elemental analyzer techniques. Rapid Communications in Mass Spectrometry, 20(19), 2915-2920, doi:10.1002/rcm.2688.

Summons, R.E., Powell, T.G., 1986. Chlorobiaceae in Palaeozoic seas revealed by biological markers, isotopes and geology. Nature, 319(6056), 763-765.

Suzuki, N., Yessalina, S., Kikuchi, T., 2010. Probable fungal origin of perylene in Late Cretaceous to Paleogene terrestrial sedimentary rocks of northeastern Japan as indicated 
from stable carbon isotopes. Organic Geochemistry, 41(3), 234-241, doi:10.1016/j.orggeochem.2009.11.010.

tenHaven, H.L.T., Rohmer, M., Rullkötter, J., Bisseret, P., 1989. Tetrahymanol, the most likely precursor of gammacerane, occurs ubiquitously in marine sediments. Geochimica et Cosmochimica Acta 53, 3073-3079, doi: http://dx.doi.org/10.1016/0016-7037(89)90186-5. Tulipani, S., Grice, K., Greenwood, P.F., Schwark, L., 2013. A pyrolysis and stable isotopic approach to investigate the origin of methyltrimethyltridecylchromans (MTTCs). Organic Geochemistry, 61(0), 1-5, doi:http://dx.doi.org/10.1016/j.orggeochem.2013.05.006. Tulipani, S., Grice, K. , Greenwood, P.F. , Haines, P.W., Sauer, P.E., Schimmelmann, A., Summons, R.E., Foster, C.B., Böttcher, M.E., Playton, T., Schwark, L., 2014. Changes of palaeoenvironmental conditions recorded in Late Devonian reef systems from the Canning Basin, Western Australia: A biomarker and stable isotope approach. Gondwana Research, in press.

van Kaam-Peters, H.M.E., Schouten, S., de Leeuw, J.W., Sinninghe Damsté, J.S., 1997. A molecular and carbon isotope biogeochemical study of biomarkers and kerogen pyrolysates of the Kimmeridge Clay Facies: palaeoenvironmental implications. Organic Geochemistry, 27(7-8), 399-422, doi:http://dx.doi.org/10.1016/S0146-6380(97)00084-3.

Wakeham S.G., Schaffner, C., Giger, W., Boon, J.J., De Leeuw, J.W., 1979. Perylene in sediments from the Namibian Shelf. Geochimica et Cosmochimica Acta 43, 1141-1144, doi: 10.1016/0016-7037(79)90100-5.

Wakeham S.G., Schaffner, C., Giger, W., 1980. Polycyclic aromatic hydrocarbons in Recent lake sediments-II. Compounds derived from biogenic precursors during early diagenesis. Geochimica et Cosmochimica Acta 44, 415-429, doi: 10.1016/0016-7037(80)90041-1. 
Wakeham, S.G., Amann, R., Freeman, K.H., Hopmans, E.C., Jørgensen, B.B., Putnam, I.F., Schouten, S., Sinninghe Damsté, J.S., Talbot, H.M., Woebken, D., 2007. Microbial ecology of the stratified water column of the Black Sea as revealed by a comprehensive biomarker study. Organic Geochemistry, 38(12), 2070-2097, doi:http://dx.doi.org/10.1016/j.orggeochem.2007.08.003.

Wang, L., Song, Z., Yin, Q., George, S.C., 2011. Paleosalinity significance of occurrence and distribution of methyltrimethyltridecyl chromans in the Upper Cretaceous Nenjiang Formation, Songliao Basin, China. Organic Geochemistry 42, 1411-1419, doi: http://dx.doi.org/10.1016/j.orggeochem.2011.08.012.

Wood, G., Gabriel, A., Lawson, J., 1996. Palynological techniques-processing and microscopy, 29-50 pp., American Association of Stratigraphic Palynologists Foundation. 


\section{Appendix}

\section{Supplementary figures and tables}
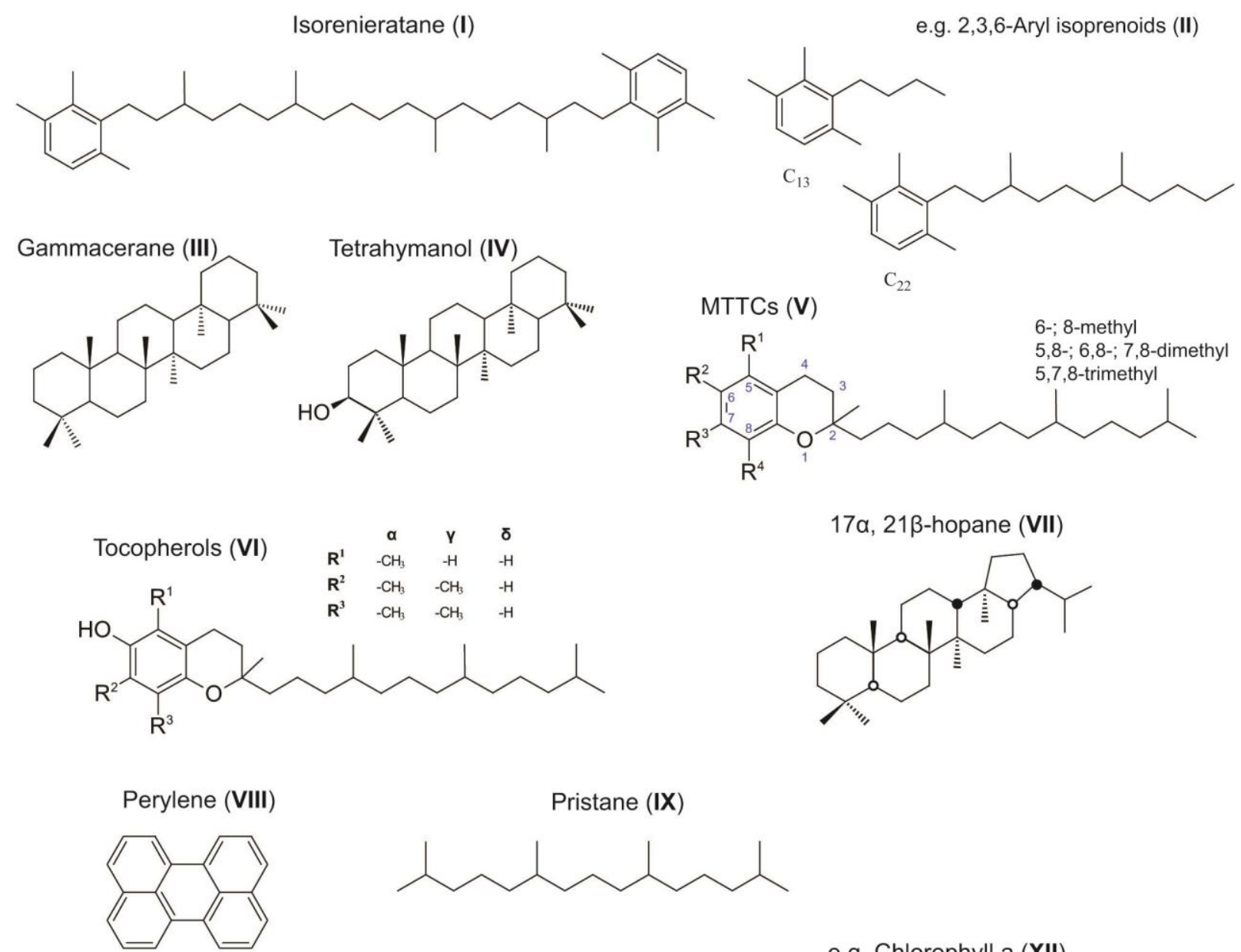

e.g. Chlorophyll a (XII)

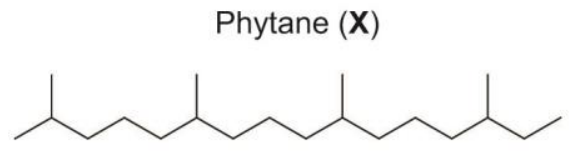

Paleorenieratane (XI)
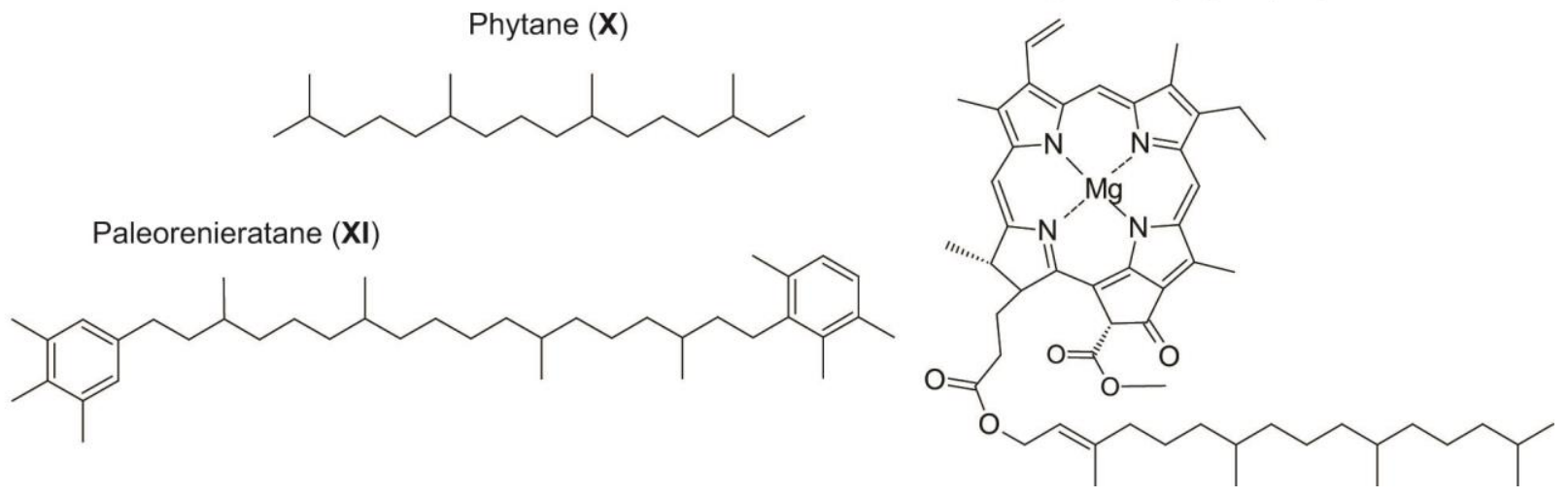

Figure A1: Structures referred to in the text 


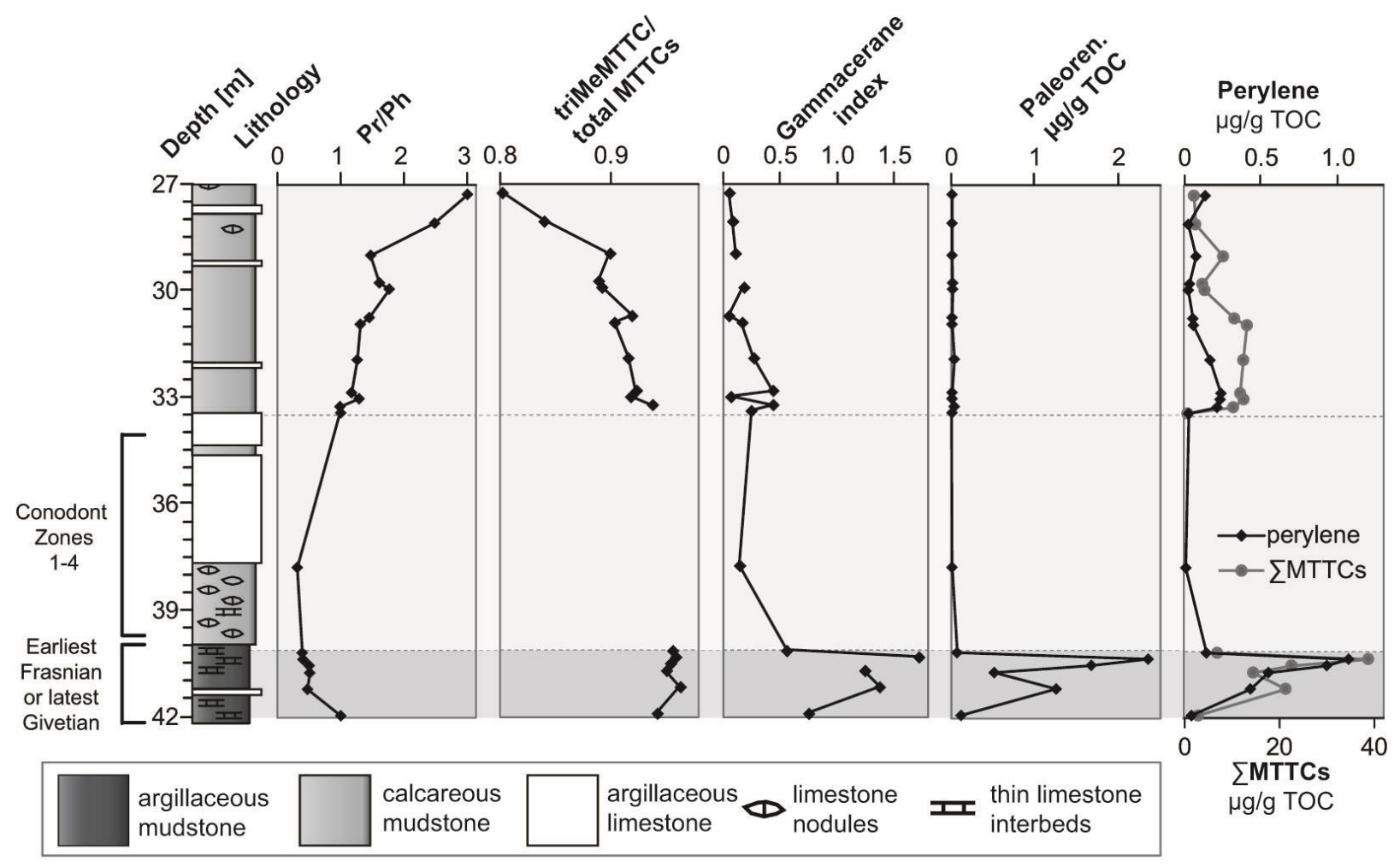

Figure A2: Lithology and depth profiles of biomarker parameters indicative of redox conditions, photic zone euxinia, water-column stratification and salinity in the investigated section of the MR-1 core; adapted from Tulipani et al. 2014. $\mathrm{Pr} / \mathrm{Ph}=$ pristane/phytane; gammacerane index = gammacerane $/ 17 \alpha, 21 \beta$ hopane; palaeoren. = palaeorenieratane; triMeMTTC/total MTTC = 5,7,8 trimethyl-2-methyltrimethyltridecylchroman/total methyltrimethyltridecylchromans, calculated from peak areas of selected ion monitoring traces 


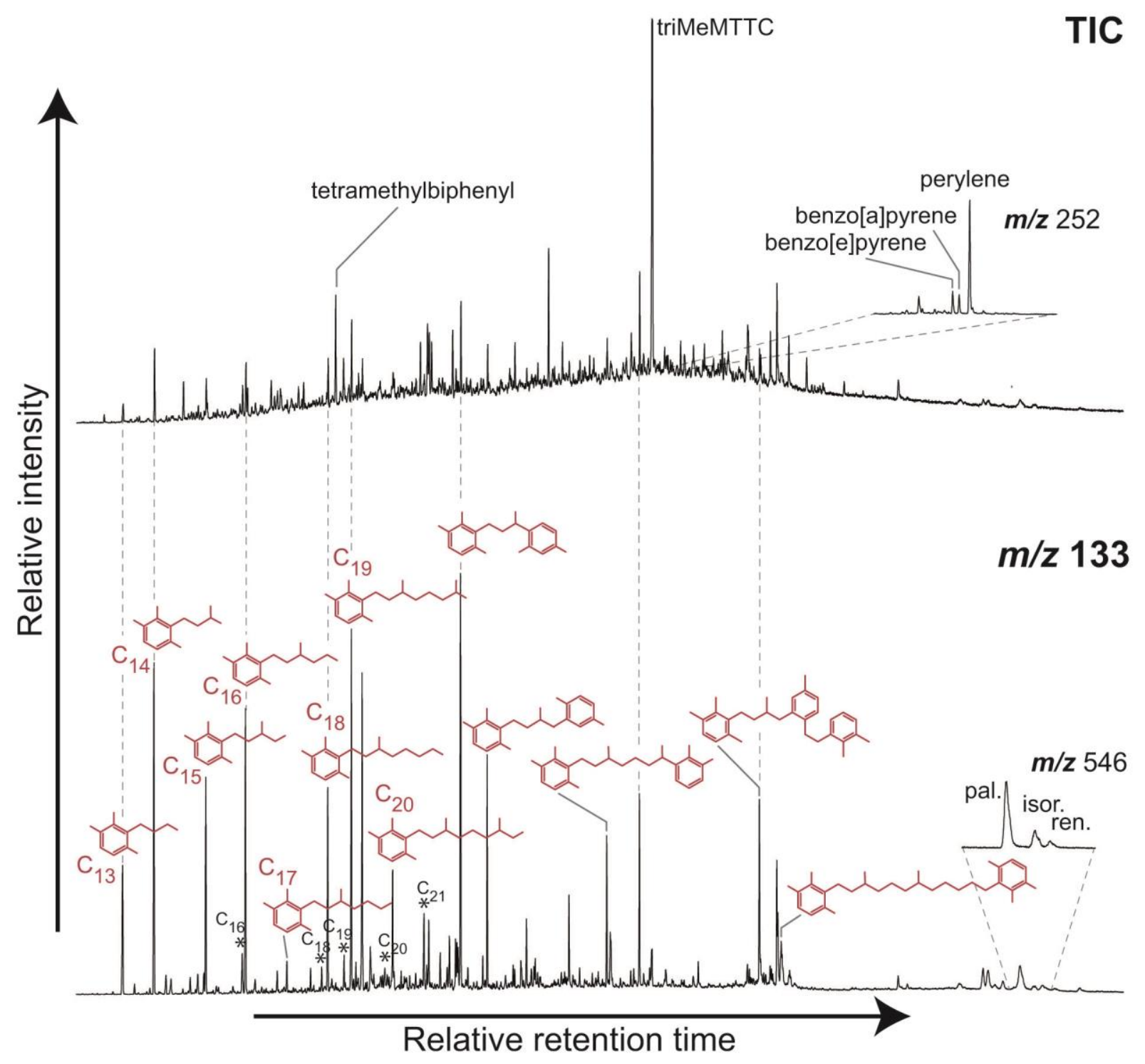

Figure A3: Arylisoprenoids, 5,7,8-trimethylmethyltrimethyltridecylchroman (triMeMTTC) and perylene in a typical aromatic fraction from the restricted Late Givetian-Early Frasnian paleoenvironment. Asterisks mark 3,4,5-arylisoprenoids; pal. = paleorenieratane, isor. $=$ isorenieratane, ren. $=$ renieratane 
Table A1: Selected maturity data and bulk $\delta^{13} \mathrm{C}$ values throughout the MR-1 core from Tulipani et al. (2014). HI = Hydrogen index; OI = Oxygen index; $\mathrm{T}_{\max }$, HI and OI was determined by Rock Eval analysis. Ts $=18 \alpha$ 22,29,30-trisnorhopane; $\mathrm{Tm}=17 \alpha$ 22,29,30-trisnorhopane. $\mathrm{C}_{29}$ $\alpha \alpha \alpha \mathrm{St}=5 \alpha, 14 \alpha, 17 \alpha 24$-ethylcholestane; S and R represent the stereochemistry at C20.

\begin{tabular}{|c|c|c|c|c|c|c|c|}
\hline $\begin{array}{l}\text { Medium } \\
\text { depth } \\
{[\mathrm{m}]}\end{array}$ & $\mathbf{T}_{\max }\left[{ }^{\circ} \mathbf{C}\right]$ & $\begin{array}{l}\mathrm{HI} \\
{[\mathrm{mg} \mathrm{HC} / \mathrm{g} \mathrm{TOC}]}\end{array}$ & $\begin{array}{l}\text { Ol } \\
{\left[\mathrm{mg} \mathrm{CO}_{2} / \mathrm{g} \mathrm{TOC}\right]}\end{array}$ & $\mathrm{Ts} /(\mathrm{Ts}+\mathrm{Tm})$ & $\begin{array}{l}\mathrm{C}_{29} \alpha \alpha \alpha \mathrm{St} \\
\mathrm{S} /(\mathrm{S}+\mathrm{R})\end{array}$ & $\delta^{13} \mathrm{Com}_{0}$ & $\delta^{13} C_{\text {carb. }}$ \\
\hline 27.3 & 413 & 70 & 102 & 0.14 & 0.14 & -29.74 & 1.00 \\
\hline 28.1 & 410 & 72 & 108 & 0.15 & 0.15 & -29.88 & 0.67 \\
\hline 29.0 & 418 & 115 & 35 & 0.13 & 0.12 & -28.25 & 1.56 \\
\hline 29.7 & 409 & 124 & 71 & n.d. & n.d. & -28.19 & 1.56 \\
\hline 29.9 & 407 & 101 & 51 & 0.14 & 0.04 & n.d. & n.d. \\
\hline 30.7 & 405 & 105 & 42 & 0.14 & 0.12 & n.d. & n.d. \\
\hline 30.9 & 421 & 166 & 32 & 0.14 & 0.11 & -28.40 & 1.15 \\
\hline 31.9 & 405 & 131 & 48 & 0.16 & 0.11 & -27.83 & 1.42 \\
\hline 32.8 & 406 & 107 & 46 & 0.18 & 0.10 & -28.56 & 1.60 \\
\hline 33.0 & 410 & 128 & 57 & 0.18 & 0.11 & n.d. & n.d. \\
\hline 33.2 & 415 & 116 & 44 & 0.19 & 0.10 & -28.30 & 1.90 \\
\hline 33.4 & 410 & 82 & 82 & 0.18 & 0.08 & -27.23 & 1.18 \\
\hline 37.8 & n.d. & n.d. & n.d. & 0.47 & 0.19 & -25.04 & 3.16 \\
\hline 40.2 & n.d. & n.d. & n.d. & 0.22 & 0.08 & -28.97 & 0.11 \\
\hline 40.3 & 415 & 252 & 39 & 0.16 & 0.09 & -29.59 & -3.01 \\
\hline 40.5 & 413 & 223 & 28 & n.d. & n.d. & n.d. & n.d. \\
\hline 40.7 & 414 & 211 & 42 & 0.13 & 0.09 & -28.69 & 0.65 \\
\hline 41.2 & 410 & 264 & 32 & 0.10 & 0.09 & -29.01 & -1.63 \\
\hline 41.9 & 413 & 169 & 52 & 0.11 & 0.09 & -29.21 & 0.05 \\
\hline
\end{tabular}


Table A2: Data included in Figure 2.

\begin{tabular}{|c|c|c|c|c|c|c|c|c|}
\hline \multirow[b]{2}{*}{$\begin{array}{l}\text { Medium } \\
\text { depth } \\
{[\mathrm{m}]}\end{array}$} & \multirow[b]{2}{*}{$\begin{array}{l}\text { *Chroman } \\
\text { Ratio }\end{array}$} & \multirow[b]{2}{*}{$\begin{array}{l}\text { triMeMTTC } \\
{[\mu \mathrm{g} / \mathrm{g} \text { TOC] }}\end{array}$} & \multirow[b]{2}{*}{${ }^{*} \mathrm{Pr} / \mathrm{Ph}$} & \multirow[b]{2}{*}{$\begin{array}{l}\text { *Gammacerane } \\
\text { Index }\end{array}$} & \multirow[b]{2}{*}{$\begin{array}{l}\text { *Perylene } \\
{[\mu \mathrm{g} / \mathrm{g} \text { TOC] }}\end{array}$} & \multirow[b]{2}{*}{$\begin{array}{l}\text { *Paleorenieratane } \\
\text { [ } \mu \mathrm{g} / \mathrm{g} \text { TOC] }\end{array}$} & \multicolumn{2}{|c|}{$\delta^{13} \mathrm{C}[\% \circ$ VPDB] } \\
\hline & & & & & & & triMeMTTC & *phytane \\
\hline 27.3 & 0.79 & 1.45 & 2.99 & 0.05 & 0.13 & 0.00 & n.d. & n.d. \\
\hline 28.1 & 0.83 & 1.76 & 2.47 & 0.08 & 0.02 & 0.00 & -33.4 & n.d. \\
\hline 29.0 & 0.89 & 7.11 & 1.47 & 0.11 & 0.07 & 0.00 & -31.1 & -31.7 \\
\hline 29.7 & 0.88 & 3.17 & 1.61 & n.d. & 0.03 & 0.00 & n.d. & n.d. \\
\hline 29.9 & 0.88 & 3.56 & 1.76 & 0.18 & 0.02 & 0.01 & n.d. & n.d. \\
\hline 30.7 & 0.91 & 9.41 & 1.45 & 0.05 & 0.05 & 0.00 & n.d. & n.d. \\
\hline 30.9 & 0.89 & 11.60 & 1.31 & 0.16 & 0.05 & 0.00 & -31.1 & -31.2 \\
\hline 31.9 & 0.91 & 11.00 & 1.26 & 0.27 & 0.16 & 0.03 & -30.7 & -31.7 \\
\hline 32.8 & 0.91 & 10.55 & 1.17 & 0.43 & 0.23 & 0.00 & n.d. & n.d. \\
\hline 33.0 & 0.91 & 11.13 & 1.29 & 0.06 & 0.23 & 0.00 & -31.8 & n.d. \\
\hline 33.2 & 0.93 & 9.38 & 0.99 & 0.43 & 0.21 & 0.02 & -31.3 & -32.0 \\
\hline 33.4 & n.d. & 0.36 & 1.00 & 0.24 & 0.02 & 0.00 & n.d. & -31.4 \\
\hline 37.8 & n.d. & n.d. & 0.32 & 0.14 & 0.00 & 0.00 & -33.4 & -33.5 \\
\hline 40.2 & 0.95 & 6.38 & 0.39 & 0.55 & 0.14 & 0.06 & -33.2 & -33.6 \\
\hline 40.3 & 0.95 & 36.55 & 0.41 & 1.71 & 1.06 & 2.34 & n.d. & n.d. \\
\hline 40.5 & 0.94 & 21.16 & 0.51 & n.d. & 0.92 & 1.66 & n.d. & n.d. \\
\hline 40.7 & 0.94 & 13.44 & 0.51 & 1.24 & 0.54 & 0.50 & -33.2 & -32.7 \\
\hline 41.2 & 0.95 & 20.18 & 0.48 & 1.37 & 0.42 & 1.24 & n.d. & n.d. \\
\hline 41.9 & 0.93 & 2.50 & 1.00 & 0.75 & 0.04 & 0.11 & -33.1 & -33.9 \\
\hline
\end{tabular}

*Also published in Tulipani et al. 2014 